Volume 55

Issue 1 Volume 55, Issue 1 (Winter 2018)

The CJPTA: A Decade of Progress

Article 4

Guest editors: Janet Walker, Gerard Kennedy,

and Sagi Peari

$5-16-2018$

\title{
Has the CJPTA readied Canada for the Hague Choice of Court Convention?
}

Geneviève Saumier

Faculty of Law, McGill University

Follow this and additional works at: https://digitalcommons.osgoode.yorku.ca/ohlj

Part of the Courts Commons

Article

c) (i) (3)

This work is licensed under a Creative Commons Attribution-Noncommercial-No Derivative Works 4.0 License.

\section{Citation Information}

Saumier, Geneviève. "Has the CJPTA readied Canada for the Hague Choice of Court Convention?." Osgoode Hall Law Journal 55.1 (2018) : 141-162.

https://digitalcommons.osgoode.yorku.ca/ohlj/vol55/iss1/4

This Article is brought to you for free and open access by the Journals at Osgoode Digital Commons. It has been accepted for inclusion in Osgoode Hall Law Journal by an authorized editor of Osgoode Digital Commons. 


\title{
Has the CJPTA readied Canada for the Hague Choice of Court Convention?
}

\begin{abstract}
This paper examines whether the Court Jurisdiction and Proceedings Transfer Act has readied Canada to adopt the 2005 Hague Choice of Court Convention. Reviewing the Hague Convention as well as previous and current law and cases on forum selection clauses in common law Canada, including the very recent Supreme Court of Canada decision in Douez v Facebook, yields two conclusions. First, there are existing interpretive challenges flowing from gaps in the CJPTA with respect to jurisdictional clauses that need to be addressed. Second, the principles governing forum selection clauses in Canada are largely consistent with those put forward in the Hague Convention and should not be perceived as obstacles to its adoption.
\end{abstract}

\section{Keywords}

Hague Convention on Choice of Court Agreements (2005 June 30); Jurisdiction; Canada

\section{Creative Commons License}

\section{(c) (i) (9)}

This work is licensed under a Creative Commons Attribution-Noncommercial-No Derivative Works 4.0 License.

\section{Cover Page Footnote}

I would like to thank Vaughan Black and Mahmud Jamal for insightful comments on the first version of this paper, which I have tried to address in this revised version. I would also like to thank Catherine Walsh for helpful comments on further revisions made necessary following the Supreme Court of Canada's decision in Douez v Facebook, rendered on 23 June 2017. 


\title{
Special Issue
}

The CJPTA: A Decade of Progress

\section{Has the CJPTA readied Canada for the Hague Choice of Court Convention?}

\author{
GENEVIÈVE SAUMIER*
}

This paper examines whether the Court Jurisdiction and Proceedings Transfer Act has readied Canada to adopt the 2005 Hague Choice of Court Convention. Reviewing the Hague Convention as well as previous and current law and cases on forum selection clauses in common law Canada, including the very recent Supreme Court of Canada decision in Douez v Facebook, yields two conclusions. First, there are existing interpretive challenges flowing from gaps in the CJPTA with respect to jurisdictional clauses that need to be addressed. Second, the principles governing forum selection clauses in Canada are largely consistent with those put forward in the Hague Convention and should not be perceived as obstacles to its adoption.

I. FORUM SELECTION CLAUSES IN THE PRE-CJPTA PERIOD AND IN THE CJPTA

Peter M. Laing Chair, Faculty of Law, McGill University. I would like to thank Vaughan Black and Mahmud Jamal for insightful comments on the first version of this paper, which I have tried to address in this revised version. I would also like to thank Catherine Walsh for helpful comments on further revisions made necessary following the Supreme Court of Canada's decision in Douez v Facebook, rendered on 23 June 2017. 
IT IS WELL ESTABLISHED THAT CANADIAN COURTS recognize international jurisdiction based on consent and that such consent can be expressly given in advance by way of a contractual agreement, variously described as a forum selection clause, jurisdiction clause, or choice of court agreement. This is the case across the country, prescribed in Quebec by article 3148 of the Civil Code and consistently admitted by courts in the common law provinces. A central distinguishing factor between Quebec and the rest of the country is the absence in the former of any discretion to disregard a forum selection clause that designates a foreign court, whereas such a discretion, albeit very circumscribed, remains available in the latter. ${ }^{1}$ A second significant difference is that Quebec law specifically exempts consumers and employees from the general rule, declaring that they are not bound by such clauses. ${ }^{2}$ Again, there is no equivalent express exception in the rest of the country. ${ }^{3}$ Both of these distinctions are relevant to the Hague Choice of Court Convention, as will be discussed further below.

The Hague Choice of Court Convention came into force on 1 October 2015, ${ }^{4}$ following its ratification by Mexico and the European Union. ${ }^{5}$ It has also been signed by the United States, Ukraine, and Singapore, albeit only ratified by Singapore. As a result of these ratifications, it will be applicable in jurisdictions from both civil law and common law traditions. Its main objective is to establish the validity of the jurisdiction of courts designated in forum selection clauses, and to mandate the enforcement of these clauses, in addition to the subsequent recognition and enforcement of judgments rendered by courts designated by these clauses. Although Canada has yet to sign the Hague Convention, the Uniform

1. For a detailed consideration of this issue, see Geneviève Saumier \& Jeffrey Bagg, "Forum Selection Clauses before Canadian Courts: A Tale of Two (or Three?) Solitudes" (2013) 46:2 UBC L Rev 439.

2. Art 3149 CCQ.

3. Although consumers or employees may be able to avoid the clause by invoking contract defences or public policy. In the employment context, see e.g. Stubbs v ATS International BV, 2010 ONCA 879 at para 58, 272 OAC 386; Douez v Facebook, 2017 SCC 33, 411 DLR (4th) 434 [Facebook].

4. Hague Convention of 30 June 2005 on Choice of Court Agreements, 30 June 2005, Hague Conference on Private International Law (entered into force 1 October 2015), online: <www. hcch.net/en/instruments/conventions/full-text/?cid=98> [Hague Convention].

5. As between member states of the European Union, the Brussels regime pre-empts the Hague Convention regime. 
Law Conference of Canada ("ULCC") adopted a model implementation statute in $2010 .^{6}$

This article examines whether the Court Jurisdiction and Proceedings Act ("CJPTA") ${ }^{7}$ has readied Canada to adopt the Hague Convention. To answer this question, I will consider how the CJPTA deals with forum selection clauses with a view to identifying points of consensus or dissension between it and the Hague Convention. My conclusion is that, while the law governing forum selection clauses in CJPTA jurisdictions in Canada is largely compatible with the broad policy objectives underlying the Hague Convention, the CJPTA itself hinders rather than helps establish the conditions for adoption of the Hague Convention. The adoption of the Hague Convention by Canada would, however, provide an added incentive to make amendments to the CJPTA that are necessary to provide clarity and predictability in the treatment of forum selection clauses in CJPTA jurisdictions.

This article will take a chronological approach to the issue. The first part will review the state of the law on forum selection clauses prior to the adoption of the CJPTA by the ULCC in 1994 and examine how the CJPTA deals with these clauses. The second part will consider how the law developed from 1994 onwards and how this affected the interpretation of jurisdiction clauses under the CJPTA, which first came into force in Saskatchewan only ten years later in 2004. It will also consider the impact of the Supreme Court of Canada's recent decision in Douez $v$ Facebook. The third part will then provide a brief overview of the Hague

6. See Hague Convention on Choice of Court Agreements Act (2010), Uniform Law Conference of Canada, online: <www.ulcc.ca/en/uniform-acts-new-order/current-uniform-acts/645-hagueconvention-choice-of-court/1404-hague-convention-on-choice-of-court-agreements-act> . See also Vaughan Black, "The Hague Choice of Court Convention and the Common Law" (Paper delivered at the Annual Proceedings of the Uniform Law Conference of Canada, Charlottetown, September 2007), online: <ssrn.com/abstract=2116549> [Black, "Hague and Common Law"]; Frédérique Sabourin, "Quebec Law and the Hague Convention of Choice of Court Agreements of 2005" (Paper delivered at the Annual Proceedings of the Uniform Law Conference of Canada, Charlottetown, September 2007), online: <www.ulcc.ca/en/ uniform-acts-new-order/current-uniform-acts/645-hague-convention-choice-of-court/1509hague-convention-choice-of-court-agreement-quebec-law-2007>.

7. See Uniform Law Conference of Canada, Proceedings of the Seventy-Sixth Annual Meeting, 1994, Appendix C: Court Jurisdiction and Proceedings Transfer Act, online: <www.ulcc.cal images/stories/1994_EN_pdf/1994ulcc0008_Court_Jurisdiction_Proceedings_Transfer_Act. pdf $>$ at $140[C J P T A]$. This is a model Act published by the Uniform Law Conference of Canada (ULCC). Three jurisdictions in have brought the CJPTA into force-British Columbia, Nova Scotia, and Saskatchewan. See Court Jurisdiction and Proceedings Transfer Act, SBC 2003, c 28; Court Jurisdiction and Proceedings Transfer Act, SNS 2003 (2nd Sess), c 2; The Court Jurisdiction and Proceedings Transfer Act, SS 1997, c C-41.1. 
Convention to squarely address the question of whether the CJPTA facilitates or hinders the adoption of that Convention.

\section{FORUM SELECTION CLAUSES IN THE PRE-CJPTA PERIOD AND IN THE CJPTA}

Prior to the introduction of the CJPTA in 1994, courts in the common law provinces largely approached the enforcement of forum selection clauses in a similar manner. Thus, a plaintiff could institute proceedings in the court designated by the clause and this alone was sufficient grounds for service ex juris. ${ }^{8}$ Where the plaintiff sought to begin proceedings in a court other than the contractually agreed-upon one, Canadian common law courts also followed a similar approach. For example, in 1988, the Prince Edward Island Court of Appeal reviewed English and Canadian cases and concluded that a "properly framed contractual choice of forum ... should be upheld unless the [plaintiff] can establish that the balance of convenience massively favours an opposite conclusion." In so holding, the court referred specifically to a similar conclusion by the Court of Appeal of Alberta three years earlier. ${ }^{10}$ The British Columbia Court of Appeal considered that "Canadian courts will respect contracting parties' choice of forum to resolve disputes arising from their contractual relationship unless there is strong cause to override the agreement." ${ }^{11}$ In other words, Canadian common law courts were prepared to give effect to a forum selection clause, whether the clause conferred jurisdiction on them or another court. This view was implicitly approved by the Supreme Court of Canada's landmark decision in Morguard Investments Ltd

8. For an overview of service rules see Black, "Hague and Common Law," supra note 6 at paras 39-62. Appropriate service was sufficient to establish the jurisdiction of the court, notwithstanding the absence of any other connection between the defendant or the claim and the court. Of course, the conferral of jurisdiction by consent does not extend to subject-matter jurisdiction. See e.g. Stephen GA Pitel \& Nicholas S Rafferty, Conflict of Laws, 2nd ed (Toronto: Irwin Law, 2016) at 70.

9. Oulton Agencies Inc v Knolloffice Inc, 69 Nfld \& PEIR 65 at para 23, 48 DLR (4th) 545.

10. Ibid at paras 21-22, citing Volkswagen Canada Inc v Auto Haus Froblich Ltd (1985), 65 AR 271, [1986] 1 WWR 380 (CA).

11. Sarabia $v$ The Oceanic Mindoro (1996), 26 BCLR (3d) 143 at para 35, [1997] 2 WWR 116 (CA) [Sarabia]. This decision is subsequent to the adoption of the CJPTA by the ULCC but prior to its adoption by the British Columbia legislature in 2003 and coming into force in 2006. It is worth noting that the court in Sarabia enforced a forum selection clause in an employment contract. 
$v$ De Savoye in 1990, where jurisdiction based on consent was declared to be "appropriate," even though that case did not refer to forum selection clauses. ${ }^{12}$

Typically, if a court has jurisdiction, a defendant can seek a stay on grounds of forum non conveniens. ${ }^{13}$ Nothing in the forum non conveniens doctrine excludes its application where a court derives its jurisdiction from a forum selection clause. However, the language quoted previously from courts dealing with such clauses designating a foreign court suggested a different test for the exercise of discretion with regard to a forum selection clause. In such a case, the party seeking to avoid the clause must show a "strong cause" why it should not be enforced, or show that the "balance of convenience" massively favours that result. The British Columbia Court of Appeal further stated that the "strong cause' that the plaintiff must show" must go "beyond mere balance of convenience." ${ }^{14}$ As the main argument supporting this position was that parties should be held to their bargain, there was no reason in principle for the test to be different depending on whether the court was the designated or the excluded court. Despite this possible ambiguity on the role of forum non conveniens in cases involving jurisdiction clauses, at the time the CJPTA was adopted the exact features of the discretion did not appear to be a contentious issue.

When the ULCC put forward the CJPTA, it was intended to "bring Canadian jurisdictional rules into line with the principles laid down by the SCC in Morguard Investments and Amchem Products." 15 As noted previously, these two cases were not concerned with, nor did they even mention, forum selection clauses. Morguard Investments did, however, specifically state that consent had been, and remained, a legitimate basis for international jurisdiction. The CJPTA expressly states that it is the sole source for the determination of "territorial competence" of courts in the enacting jurisdiction. ${ }^{16}$ The commentary explains that this is "to make it clear that a court's territorial competence is to be determined according to the rules in the Act and not according to any 'common law' jurisdictional rules

12. Morguard Investments Ltd v De Savoye, [1990] 3 SCR 1077 at 1093, 76 DLR (4th) 256 [Morguard Investments].

13. The contours of that doctrine had been revised by the SCC in the 1993 decision Amchem Products Incorporated v British Columbia (Workers' Compensation Board), but it did not deal at all with forum selection clauses. See Amchem Products Incorporated $v$ British Columbia (Workers' Compensation Board), [1993] 1 SCR 897, 102 DLR (4th) 96 [Amchem Products].

14. Sarabia, supra note 11 at para 38 [emphasis added].

15. See introductory comments in CJPTA, supra note 7.

16. Ibid, s 2(2). 
that the Act replaces." ${ }^{17}$ This invites an interpretation of the CJPTA that excludes recourse to common law rules, past, present or future. ${ }^{18}$

The CJPTA also claimed to have "codified" the doctrine of forum non conveniens as expressed by the SCC in Amchem Products. The commentary to section 11 states that the "factors listed in section 11(2) ... have been expressly or implicitly considered by courts in the past." ${ }^{19}$ One might quibble that forum non conveniens does not "determine" a court's territorial competence but rather informs its decision to decline to exercise that competence. ${ }^{20}$ In that sense, the admonition of the ULCC not to refer to common law in interpreting the CJPTA might not apply to that section. On the other hand, the commentary does refer to both Morguard Investments and Amchem Products as sources for the CJPTA's "jurisdictional rules," suggesting that to the ULCC, both section 3 (on territorial competence) and section 11 (on forum non conveniens) are such rules. ${ }^{21}$

The CJPTA mentions forum selection clauses only in section 3, establishing that a court has jurisdiction if "there is an agreement between the plaintiff and [the defendant] to the effect that the court has jurisdiction in the proceeding." ${ }^{22}$ As seen above, this merely replicates the law existing at the time. The CJPTA does not expressly address the situation where the court is seized despite an agreement between the parties that any dispute will be brought before a foreign court. This is surprising because the bulk of cases up to that time concerned this very issue and not the situations involving prior agreement. There is no mention of this even in the commentary.

One might have expected that this latter issue would have been dealt with in section 11 on "discretion as to the exercise of territorial competence." This

17. Ibid.

18. See Stephen Pitel's paper for a discussion of the different answers to these questions in the CJPTA provinces. Stephen GA Pitel, "Six of One, Half a Dozen of the Other? Jurisdiction in Common Law Canada” (2018) 55:1 Osgoode Hall LJ 63.

19. I will refer to the section numbers from the ULCC model act, which are the same as those in the British Columbia Act, but not in the Nova Scotia and Saskatchewan enactments, where section 11 is numbered 12 and 10, respectively. See CJPTA, supra note 7.

20. The Supreme Court of Canada has reiterated that distinction more than once. See e.g. Club Resorts Ltd v Van Breda, 2012 SCC 17, [2012] 1 SCR 572 [Van Breda]. See also Canada Post Corp v Lépine, 2009 SCC 16, [2009] 1 SCR 549.

21. To a certain extent, the Supreme Court of Canada might be seen to have confirmed this view when it held that section 11 of the CJPTA "constitutes a complete codification of the common law test for forum non conveniens. It admits of no exceptions." See Teck Cominco Metals Ltd v Lloyd's Underwriters, 2009 SCC 11 at para 22, [2009] 1 SCR 321 [Teck Cominco].

22. See CJPTA, supra note 7, s 3. This is section 4 in Nova Scotia, but section 3 in other CJPTA jurisdictions. 
would have been consistent with the prevailing approach according to which courts had a discretion not to enforce jurisdiction clauses. But section 11 does not mention jurisdictional clauses. Instead, section 11 is of general application and applies equally to any of the jurisdictional bases enumerated in section 3 . This means that a stay can be requested even where jurisdiction is established by "an agreement between the parties" under section 3(c). And while section 11(2) provides a list of factors to be considered in deciding whether "another court is more appropriate," the existence of a forum selection clause is not included. Even though the list is not closed (meaning that the jurisdiction clause could be considered), it would still only be one element among others, since the CJPTA prescribes that the listed factors "must" be considered. ${ }^{23}$

On its face, therefore, the CJPTA does several things with respect to forum selection clauses. First, it confirms that jurisdiction can be conferred by prior consent of the parties. ${ }^{24}$ Second, it does not exclude the possibility that a stay of this jurisdiction is available. ${ }^{25}$ Third, it posits a universal approach to the exercise of that discretion to stay proceedings. In so doing, it does not codify the prevailing view at the time which was that the applicable test for that discretion is stricter or different than what might apply in the absence of a forum selection clause; nor does it confirm or deny that this stricter test applies to any forum selection clause, whether it confers or excludes the jurisdiction of the court deciding whether to stay the action. This silence has been the source of confusion and debate, as will be discussed in the next section.

\section{DEVELOPMENTS AFTER 1994: AT COMMON LAW AND UNDER THE CJPTA}

The 2003 Supreme Court of Canada decision in ZI Pompey Industrie v Ecu-Line $N V^{26}$ is the most significant development occurring between the adoption of

23. For a detailed and critical consideration of this line of reasoning, see Vaughan Black, Stephen GA Pitel \& Michael Sobkin, Statutory Jurisdiction: An Analysis of the Court Jurisdiction and Proceedings Transfer Act (Toronto: Carswell, 2012) at 207-211.

24. CJPTA, supra note $7, \mathrm{~s} 3$ (c).

25. CJPTA, supra note 7, s 11 .

26. 2003 SCC 27, [2003] 1 SCR 450 [Pompey]. 
the CJPTA by the ULCC and its coming into force in the enacting provinces. ${ }^{27}$ While endorsing the strong cause test, the Court stated the following:

There is a similarity between the factors which are to be taken into account when considering an application for a stay based on a forum selection clause and those factors which are weighed by a court considering whether to stay proceedings in "ordinary" cases applying the forum non conveniens doctrine ... but the presence of a forum selection clause ... is ... sufficiently important to warrant a different test, one where the starting point is that parties should be held to their bargain. ... I am not convinced that a unified approach to forum non conveniens, where a choice of jurisdiction clause constitutes but one factor to be considered, is preferable. ${ }^{28}$

On its own, this statement might be difficult to reconcile with an approach to forum selection clauses under the CJPTA that would treat these as one more factor in the list of factors to be considered under section 11(2). ${ }^{29}$

On the other hand, the Court endorsed a list of seven factors for evaluating strong cause from the prevailing English case, The Eleftheria, which include: location of evidence, applicable law, connection of parties, enforceability of ensuing judgment, limitation periods, availability of security for costs, and risk of an unfair trial..$^{30}$ As noted in the preceding quotation, the overlap between these factors and those for "ordinary" forum non conveniens at common law and under the CJPTA is evident. The effect of Pompey can thus better be understood as involving two elements: establishing a presumption that a (valid) forum selection clause is to be enforced, and placing a heavy burden to rebut this presumption on the party seeking a stay to avoid the enforcement of that clause. ${ }^{31}$ Admittedly, this might not be so different from the "ordinary" forum non conveniens analysis which requires that the defendant seeking to displace the forum validly chosen

27. The judgment repeatedly specifies that it is dealing with forum selection clauses in bills of lading (see ibid at paras 21-22, 24, 39), and might be interpreted to be limited to this matter. However, it has been widely cited since as generally applicable to forum selection clauses regardless of the nature of the contract involved.

28. Ibid at para 21.

29. See Facebook, supra note 3.

30. Owners of Cargo Lately Laden on Board Ship or Vessel Eleftheria v The Eleftheria (Owners) (1969), [1969] 2 All ER 641 at 645, [1970] P 94.

31. This formulation is neutral in that it allows Pompey to be relevant to both situations involving forum selection clauses: where the court seized is designated and where a foreign court is designated. 
by the plaintiff ${ }^{32}$ show that another forum is clearly more appropriate. ${ }^{33}$ It might be worth noting that in Amchem Products, the SCC held that the burden of proof was unlikely to be decisive in forum non conveniens cases. ${ }^{34}$ Whether that holds also in the face of a forum selection clause was not discussed in that case.

This incongruity in the Pompey reasoning was picked up in 2010 by the Ontario Court of Appeal in Expedition Helicopters Inc $v$ Hollywell Inc. ${ }^{35}$ In its judgment, the court put forward a much narrower set of factors for assessing "strong cause" that excluded those going to the balance of convenience and others typical of a forum non conveniens analysis. ${ }^{36}$ Because Ontario has not adopted the CJPTA, the Court of Appeal was obviously not concerned with trying to fit such a proposal within the CJPTA. This revised version of the "strong cause" test has been noted in CJPTA jurisdictions, although without any apparent consideration of its implications on the way in which forum selection clauses are to be analyzed under that statute. ${ }^{37}$

The first, and most significant, decision for CJPTA jurisdictions came from the SCC in a 2009 case coming from British Columbia. In Teck Cominco Metals Ltd $v$ Lloyd's Underwriters, the defendant sought a stay of BC proceedings on the basis that parallel proceedings were already pending in Washington State. In so doing, the defendant argued that the decision to stay should not depend on section 11, but rather should be granted on the basis of comity, respecting the

32. This follows from the fact that jurisdiction must be established or admitted prior to considering forum non conveniens.

33. See Van Breda, supra note 20 at paras 101-112. The Supreme Court of Canada reiterates this and glosses over the fact that the CJPTA does not use the word "clearly." Courts in CJPTA jurisdictions have since interpreted section 11 with reference to Van Breda and the "clearly more appropriate" standard. See e.g. JTG Management Services Ltd v Bank of Nanjing Co Ltd, 2015 BCCA 200 at paras 42-47, 372 BCAC 94; Frank and Ellen Remai Foundation Inc $v$ Bennett Jones LLP, 2016 SKQB 213 at paras 40-42, 269 ACWS (3d) 669; Armoyan v Armoyan, 2013 NSCA 99 at para 219, 334 NSR (2d) 204 [Armoyan].

34. See Geneviève Saumier, "Judicial Jurisdiction in International Cases: The Supreme Court's Unfinished Business" (1995) 18:2 Dal LJ 447 for a discussion of that aspect of Amchem Products and the challenge it posed in later cases, notably Frymer $v$ Brettschneider (1994), 19 OR (3d) 60, 115 DLR (4th) 744 (CA).

35. 2010 ONCA 351 at para 11, 100 OR (3d) 241 [Expedition Helicopters], leave to appeal to SCC refused, 33790 (25 November 2010). For a detailed discussion see Saumier \& Bagg, supra note 1 at $458-462$.

36. Expedition Helicopters, supra note 35 at para 24.

37. See e.g. Viroforce Systems Inc v RéD Capital Inc, 2011 BCCA 260 at para 16, 336 DLR (4th) 570 [Viroforce]; Microcell Communications Inc v Frey, 2011 SKCA 136 at para 115, 342 DLR (4th) 513 [Microcell]; Armoyan, supra note 33 at para 329. 
foreign court's concrete assertion of jurisdiction. ${ }^{38}$ In the alternative, the defendant asked that the assertion of jurisdiction by the foreign court be considered to have greater weight than other factors in a section 11 analysis. The SCC rejected both arguments. In response to the second argument, the Court said the following:

$[\mathrm{H}]$ ad actual assertion of jurisdiction by a foreign court been seen as a factor that should override all others, one would have expected the legislature to have stated this expressly. Rather, avoidance of multiplicity of proceedings is simply listed along with other factors. This suggests that the existence of foreign proceedings is only one factor, among many, to be considered in a forum non conveniens analysis. ${ }^{39}$

One might make the same argument about forum selection clauses. If the CJPTA legislators had seen these as factors to be weighted differently, they would have stated this expressly. Unlike in Teck Cominco, where the factor of "multiple proceedings" was at least included in the list of factors (and was therefore admitted to be relevant), jurisdictional clauses are not even mentioned in section 11. Regarding the more dramatic claim that the CJPTA did not address how to deal with parallel proceedings at all, the SCC responded in this manner:

The CJPTA creates a comprehensive regime that applies to all cases where a stay of proceedings is sought on the ground that the action should be pursued in a different jurisdiction (forum non conveniens). It requires that in every case ... all the relevant factors listed in $s .11$ be considered in order to determine if a stay of proceedings is warranted. ${ }^{40}$

The Court added that "section 11 of the CJPTA thus constitutes a complete codification of the common law test for forum non conveniens. It admits of no exceptions." ${ }^{41}$ Combined with the previous statement from Pompey, these two statements from Teck Cominco might be understood to confirm that forum selection clauses are not included in section 11 of the CJPTA. In other words, if the test relevant to forum selection clauses is not the same as the test for forum non conveniens, then the fact that section 11 is only a codification of forum non conveniens means that it is not applicable to forum selection clauses. While this allows for some reconciliation of the two Supreme Court of Canada cases, it does not necessarily assist courts in CJPTA jurisdictions dealing with forum selection clauses. Moreover, because the factors for "strong cause" from Pompey are largely equivalent to those found in section 11 CJPTA for forum non conveniens,

38. Teck Cominco, supra note 21 at para 17. The decision reports that a stay of proceedings had been sought in Washington, but was refused.

39. Ibid at para 25 .

40. Ibid at para 21.

41. Ibid at para 22 . 
it is challenging to maintain in practice the theoretical distinction between the two suggested by Pompey. The different approaches taken in the early CJPTA jurisprudence in British Columbia and Saskatchewan, to which I now turn, confirm these interpretive challenges. ${ }^{42}$

The British Columbia Court of Appeal was called upon in 2011 and 2012 to consider forum selection clauses (both designating foreign courts). In the first case, Viroforce Systems $v$ ReD Capital, ${ }^{43}$ the court held that the test was prescribed by Pompey and was a separate inquiry that should be conducted prior to an inquiry under section 11 of the CJPTA. In the second case, Preymann $v$ Ayus Technology Corp, ${ }^{44}$ the court confirmed this approach, holding in addition that it was consistent with Pompey and did not conflict with the Supreme Court of Canada's statements in Teck Cominco regarding the nature and scope of section 11 of the CJPTA.

Two decisions from the Court of Appeal for Saskatchewan purported to agree with Viroforce that Pompey continues to be relevant to the assessment of forum selection clauses. But in Microcell Communications v Frey, the court added that because these clauses are to be considered in response to requests for stays of proceedings, it is section 11 of the CJPTA that provides the framework..$^{45}$ This was reiterated in Hudye Farms $v$ Canadian Wheat Board - handed down the same day — but with the added caveat that "the presence of a forum selection clause is not just one factor among many contained in s[ection] $11 . " 46$

One might ask whether there is really any difference between the two approaches in practice. The answer is not obvious upon a reading of the cases from

42. The courts in Nova Scotia have not squarely faced this issue. Decisions concerning forum selection clauses appear to proceed on the understanding that the strong cause test from Pompey applies with no real consideration of how this fits within the CJPTA analysis. See e.g. 2288450 Ontario Ltd v Novajet, 2016 NSSC 77, 373 NSR (2d) 79 [Novajet]; Instrument Concepts-Sensor Software Inc v Geokinetics Acquisition Company, 2012 NSSC 62, 313 NSR (2d) 200; Curves International, Inc v Archibald, 2011 NSSC 217, 303 NSR (2d) 288 [Curves].

43. Viroforce, supra note 37.

44. 2012 BCCA 30, 346 DLR (4th) 541.

45. Microcell, supra note 37 at para 112. The court here refers specifically to "the fair and efficient working of the Canadian legal system as a whole" as outlined in section 11(2)(f) of the CJPTA. See CJPTA, supra note 7. For a criticism of this, and for other cases relying on the listed factors in section 11 of the CJPTA, see Black, Pitel \& Sobkin, supra note 23 at 207-08.

46. Hudye Farms v Canadian Wheat Board, 2011 SKCA 137 at para 11, 342 DLR (4th) 659. Vaughan Black provides a detailed analysis of this case, particularly regarding the often forgotten transfer aspect of the CJPTA. See Vaughan Black, "Cross-Border Transfers of Court Proceedings" (2018) 55:1 Osgoode Hall LJ 239. See also Black, "Hague and Common Law," supra note 6. 
the CJPTA jurisdictions. Indeed, if the factors from Pompey are largely equivalent to those in section 11, and if all courts agree that the onus is on the party seeking to avoid the clause to show the "strong cause," then whether one works within section 11 or outside of it, there is not much to distinguish the approaches. The difference would only arise if the reference to the section 11 analysis weakens the impact of the forum selection clause by putting it on par or only slightly ahead of the other factors. ${ }^{47}$ But the Court of Appeal for Saskatchewan rejected this explicitly in Hudye Farms, as noted above. What would make a difference, however, would be the substitution of the factors outlined in Expedition Helicopters for those previously endorsed in Pompey. Such an approach would eliminate the option of inserting the forum selection clause analysis within section 11, since the criteria would be distinct. But Expedition Helicopters has not made any real inroads in the CJPTA provinces, and the SCC may have implicitly rejected that approach by referring only to Pompey and the factors used in its strong cause test in a 2012 judgment involving a forum selection clause from Ontario. ${ }^{48}$

The SCC finally had an opportunity to address forum selection clauses in the CJPTA in its 2017 Facebook decision. ${ }^{49}$ Indeed, at the British Columbia Court of Appeal level, the interpretive challenge was stated expressly:

47. Whatever the approach, there does seem to be more cases than anticipated where a "strong cause" is found to exist under the Pompey factors. See e.g. Ping Leung v APK Holdings, 2013 SKQB 382, 431 Sask R 291; Yara Belle Plaine Inc v Ingersoll Rand Co, 2014 SKQB 254, [2014] 11 WWR 140; Naturex $v$ United Naturals, 2016 BCSC 1500, 270 ACWS (3d) 73; Curves, supra note 42; Novajet, supra note 42; Armoyan, supra note 33.

48. Momentous.ca Corp v Canadian American Association of Professional Baseball Ltd, 2012 SCC 9 at para 9, [2012] 1 SCR 359 [Momentous].

49. Facebook, supra note 3. Facebook involved a request for certification of a class action for breach of privacy rights under section 4 of the BC Privacy Act (see Privacy Act, RSBC 1996, c 373) brought against Facebook on behalf of members resident in British Columbia. Facebook sought a stay of proceedings on the basis of a forum selection clause designating California courts in its terms of use. In a 3-1-3 split decision, the action was not stayed. Three judges (Justices Karakatsanis, Wagner, and Gascon) held that the Pompey "strong cause" test applied but in a modified manner to account for the consumer context, leading them to conclude that public policy reasons (grossly uneven bargaining power in the consumer context and the enforcement of quasi-constitutional privacy rights), the interests of justice, and the balance of convenience provided the requisite "strong cause" not to enforce the otherwise valid forum selection clause. One judge (Justice Abella) held that the clause was invalid on contractual grounds. Three judges (Chief Justice McLachlin, Justice Côté and Justice Moldaver) dissented, finding that the clause was valid and enforceable as the plaintiff had not met the burden of proving a "strong cause" to avoid its application. While these issues are significant, they are beyond the scope of this paper and will not be discussed further unless necessary. 
The first issue to be considered is how the Pompey test for forum selection clauses relates to the analytical framework for forum non conveniens in the CJPTA. When the defendant relies upon a forum selection clause, should the court consider the Pompey test and then, if necessary, carry out the CJPTA analysis, or should the court consider the Pompey test as part of the CJPTA analysis?50

The British Columbia Court of Appeal had considered itself bound by its previous decisions in Viroforce and Preymann, concluding that "when the defendant relies upon a forum selection clause, the Pompey test is a separate, standalone inquiry that is conducted first. The CJPTA analysis may be conducted second, if necessary." ${ }^{51}$ The Supreme Court of Canada essentially endorsed this view, although it was sharply divided on many points, including the outcome of the case. ${ }^{52}$ The Court was, however, unanimous in holding that the CJPTA does not deal with forum selection clauses, whose enforcement remain to be considered under the common law..$^{53}$

The Court's analysis is framed by the plaintiffs assertion that forum selection clauses should be examined within the framework for forum non conveniens as provided in section 11 of the CJPTA..$^{54}$ In flatly rejecting this, the Court relies directly on Pompey and Teck Cominco: On the first to state that forum non conveniens is not the test for forum selection clauses, and on the second to state that section 11 of the CJPTA is a codification of forum non conveniens. ${ }^{55}$ For the Court, the upshot is that the CJPTA "does not supplant the common law principles underlying the enforcement of forum selection clauses," ${ }^{56}$ given that it "was never intended to replace the common law test for forum selection clauses."

50. Douez v Facebook Inc, 2015 BCCA 279 at para 21, 387 DLR (4th) 360 [Facebook CA] [emphasis in original].

51. Ibid at para 31. The idea that a British Columbia court would conclude that there is a "strong cause" to refuse enforcement of a forum selection clause and then proceed to decline jurisdiction on forum non conveniens grounds is rather farfetched.

52. Facebook, supra note 3 at paras 81-85.

53. Ibid at paras 19-21, 127-131. Admittedly, in her separate reasons, Justice Abella only refers to Pompey. See ibid at para 79.

54. Ibid at paras 19, 127.

55. Ibid at paras 19-21, 79, 127-133.

56. Ibid at para 131.

57. Ibid at para 22 . 
Three difficulties with this reasoning can be noted. First, it overlooks the fact that the CJPTA does deal with forum selection clauses in section 3(c)..$^{8}$ This makes it impossible to claim that the CJPTA does not address forum selection clauses. Take, for example, a jurisdictional clause designating British Columbia courts. If litigation is initiated in British Columbia, this clause is covered by section 3(c) of the CJPTA; if litigation is initiated in Saskatchewan, Facebook states that this clause is not covered by the CJPTA. A straightforward application of the CJPTA provides that a party trying to avoid the British Columbia court in the first scenario need only invoke section 11 and argue forum non conveniens to obtain a stay. Indeed, as noted above, section 3(c) is not exempted from the scope of application of section 11. But following Facebook, a party should be bound to a forum selection clause unless it can show a "strong cause" to avoid the contractually agreed-upon forum. One would expect that, regardless of where litigation is initiated, the test applicable to avoid a forum selection clause would be the same-assuming that the arguments of certainty and predictability justifying the enforcement of forum selection clauses apply. ${ }^{59}$ While this equivalent treatment of forum selection clauses wherever invoked is not inconsistent with the Supreme Court of Canada's conclusion in Facebook, it is difficult to reconcile with the text of the CJPTA. The Court's failure to account for section 3(c) in its reasons is unfortunate and weakens its claim that the CJPTA was never intended to deal with forum selection clauses.

The second difficulty with the decision in Facebook - which is connected to the first-is that it seems to run counter to the purpose of the CJPTA, which is to provide a statutory basis for questions of international jurisdiction that replaces,

58. Section 11 does not exclude its application to jurisdiction founded on s 3(c). See CJPTA, supra note 7 , ss 3(c), 11. This weakens the argument that forum non conveniens is not relevant to jurisdiction based on agreement. See Facebook, supra note 3. In Facebook, the finding of strong cause not to enforce the clause spared Justices Karakatsanis, Wagner, and Gascon from having to consider whether the doctrine of forum non conveniens could be invoked once strong cause had been successfully pleaded to avoid enforcement of the clause. As these judges note, Facebook abandoned its alternative forum non conveniens request before the Supreme Court of Canada (see ibid at para 9). The three dissenting judges affirm explicitly that forum non conveniens under the CJPTA remains available if a forum selection clause fails under the strong cause test (see ibid at para 131). Despite this assertion by the minority, it is difficult to imagine a situation where forum non conveniens would succeed once "strong cause" not to enforce a forum selection clause has been found.

59. Case law does not support such a distinction. For a claim to the contrary, see Novajet, supra note 42 at para 48 . 
with minimal variations, the previously existing common law sources. ${ }^{60}$ This should caution against any interpretation of the CJPTA that excludes from its scope issues that evidently go to international jurisdiction. As noted above, the aim of the CJPTA is "to make it clear that a court's territorial competence is to be determined according to the rules in the Act and not according to any 'common law' jurisdictional rules that the Act replaces." ${ }^{61}$ Yet the Court in Facebook holds specifically that the CJPTA does not exclude recourse to the common law to deal with forum selection clauses. One way around this incongruity is to contend that a forum selection clause that refers to a foreign court has the effect of excluding (or "ousting," as is commonly said) the jurisdiction of the court not chosen. Since the CJPTA's section on territorial jurisdiction is only meant to determine when courts have jurisdiction, it might be said that recourse to the common law is still relevant to define when a party might properly exclude that jurisdiction, which is essentially what the Supreme Court has said. Such a narrow reading of the CJPTA fails to account for section 11, however, since forum non conveniens is not a way of establishing jurisdiction either. Finally, the premise of this argument is also contrary to the prevailing common law view that a forum selection clause does not, in fact, oust the jurisdiction of the court; rather, it merely enforces the private bargain between the parties. ${ }^{62}$

A final difficulty with the Supreme Court of Canada's reasoning in Facebook is that it continues to assert that the test for "strong cause" is not equivalent to the test for forum non conveniens, despite the obvious similarity between the factors for both tests. It is unfortunate that the Court did not take this opportunity to consider fully the argument for a true differentiation put forward by the Court of Appeal for Ontario in Expedition Helicopters. ${ }^{63}$

As regards the central question in this article, the Supreme Court of Canada's decision in Facebook has clarified rather than changed the law relating to the interaction between forum selection clauses and the CJPTA, albeit in a rather perfunctory manner. On the other hand, it has opened the door to differential treatment of forum selection clauses in commercial and consumer contracts.

60. For discussion of the adoption of the CJPTA by the ULCC, see the text accompanying note 7.

61. CJPTA, supra note 7, s 2(2).

62. But see Pitel \& Rafferty, supra note 8 at $130-31$ for a critical discussion concerning a possible opening to that effect in the Supreme Court of Canada's decision in Momentous, supra note 48. See also Saumier \& Bagg, supra note 1 at 472.

63. Expedition Helicopters, supra note 35 . Indeed it is arguable that it had already done so implicitly in Momentous in 2012. See Momentous, supra note 48. For a detailed discussion of this point see Saumier \& Bagg, supra note 1 at 458-462. 
This might offer additional potential for compatibility of Canadian law with the Hague Convention, which is the subject of the final part of this article.

\section{THE HAGUE CHOICE OF COURT CONVENTION AND THE CJPTA}

The Hague Choice of Court Convention states in its preamble that certainty and effectiveness in the treatment of forum selection agreements enhances judicial co-operation which itself promotes the desired goals of international trade and investment. The rules of the Hague Convention are constructed to achieve maximum certainty and effectiveness by limiting the opportunities available to parties (and courts), to avoid the enforcement of forum selection clauses and the judgments rendered by courts designated by these clauses. It is thus a dual purpose convention establishing the validity of jurisdiction based on choice of court agreements and mandating the enforcement of judgments rendered by courts acting under such jurisdiction. In so doing, it also recognizes limitations to both of those aspects but seeks to circumscribe them to minimize their effect.

Regarding the jurisdictional element, the Hague Convention imposes a general rule according to which courts must enforce a valid forum selection clause. ${ }^{64}$ This translates into two variants, depending on the circumstances. First, where the court is the one designated by the clause, that court must recognize the jurisdiction conferred upon it; it can only refuse to do so if the agreement is "null and void" according to its own law. ${ }^{65}$ Moreover, the Hague Convention specifies that the court cannot decline to exercise the jurisdiction established pursuant to the parties' agreement. ${ }^{66}$ Second, where the court is not the designated court, it must "suspend or dismiss" the proceedings save in five defined situations. ${ }^{67}$

64. Hague Convention, supra note 4, art 5.

65. Ibid, arts 5(1), 5(3). Subject-matter jurisdiction and internal rules regarding venue are not affected.

66. Ibid, art 5(2). The court cannot decline jurisdiction "on the ground that the dispute should be decided in a court of another State." See also Trevor Harley \& Masato Dogauchi, Convention of 30 June 2005 on Choice of Court Agreements Explanatory Report, Hague Conference on Private International Law (2013), online: <assets.hcch.net/upload/expl37final. pdf $>$ at paras 132-33 [Explanatory Report]. According to the Explanatory Report, this is intended to exclude recourse to either forum non conveniens or lis pendens as justifications for staying or dismissing proceedings brought before the chosen court.

67. Hague Convention, supra note 4, art 6. 
Two of these relate to the validity of the agreement. ${ }^{68}$ Two others refer to practical impediments to enforcement. ${ }^{69}$ The last, and most open-ended exception, allows a court to refuse enforcement to avoid a "manifest injustice" or where enforcement would be "manifestly contrary to ... public policy." "The Explanatory Report gives little indication regarding what might qualify under this exception beyond excluding references to the fact that the clause would not be binding under domestic law. ${ }^{71}$ The Explanatory Report does, however, mention two instances of relevance here: where trial in the chosen court might not be "fair," or where the agreement was the result of fraud..$^{72}$

It is worth noting at this point that the "nullity" exception in articles 5 and 6 and the "public policy" exception in article 6 are further circumscribed by the fact that the Hague Convention applies only in international commercial cases. ${ }^{73}$ Indeed, the scope of the instrument specifically excludes purely domestic cases as well as disputes involving consumers or employees, family matters, personal injury, and real rights, among others. ${ }^{74}$ Since these are often areas where jurisdiction agreements are either prohibited or otherwise subject to restrictions under domestic law, their complete exclusion from the Hague Convention necessarily reduces the scope of the exceptions to enforcement. The Hague Convention also allows an individual state to formally declare that it will not apply to a specific matter, ${ }^{75}$ thereby further narrowing the scope of application of the "public policy" exception.

Turning to the recognition and enforcement element of the Hague Convention, it guarantees that judgments rendered by designated courts will

68. Ibid, arts 6(a), 6(b). Invalidity according to the law of the state of the chosen court (but not the lex fori) or lack of capacity according to the lex for $i$ justify a refusal to enforce the clause. See Explanatory Report, supra note 66 at paras 149-150. Unusually, the reference to the applicable law is said to include choice-of-law rules, which jeopardizes the uniformity of solutions otherwise sought-particularly with reference to the nullity of the clause.

69. Hague Convention, supra note 4, arts 6(d), 6(e). Where the chosen court has "decided not to hear the case" (ibid, art 6(e)) or where the agreement cannot "for exceptional reasons beyond the control of the parties, ... reasonably be performed" (ibid, art 6(d)).

70. Ibid, art 6(c).

71. Explanatory Report, supra note 66 at paras $152-53$.

72. Ibid at paras $188-190$. The fairness of the foreign trial is one of the factors admitted under Pompey. Fraud is arguably already covered by questions of validity of the clause.

73. Hague Convention, supra note 4, art 1.

74. Ibid, art 2 .

75. Ibid, art 21. Some provincial legislatures may thus wish to exclude the application of the Hague Convention in some particular field where provincial legislation prohibits or circumscribes the operation of forum selection clauses, in franchise or privacy legislation, for example. 
circulate amongst contracting states. ${ }^{76}$ This may be the signal achievement of the Hague Convention: ${ }^{77}$ Putting court litigation on a par with arbitration, which benefits from a generous enforcement regime under the 1958 New York Convention, ${ }^{78}$ in force across Canada and in 156 other states internationally. As with jurisdiction, the Hague Convention mandates recognition or enforcement and refusal to do so can only follow on grounds specifically provided for in the Hague Convention itself (particularly article 9). These mirror the reasons for refusal to enforce a jurisdictional clause, including validity issues, procedural justice, ${ }^{79}$ and public policy defences. ${ }^{80}$

This brief overview of the Hague Convention highlights the main differences with the treatment of forum selection clauses in Canadian common law provinces, including those that have adopted the CJPTA. While the Hague Convention replicates the principle of enforcement of jurisdiction clauses, it largely eliminates the discretion granted to Canadian common law courts, now confirmed by Facebook to be defined by the "strong cause" doctrine under Pompey and not included within the operation of section 11 of the CJPTA. Of course, that discretion can continue to operate outside the commercial field since the Hague Convention is limited to that sphere. Indeed, while the Hague Convention might be understood to imply that forum selection clauses in consumer or employment

76. Ibid, art 8 .

77. For a history of the project from a Canadian/Quebec perspective, see Jeffrey Talpis \& Nick Krnjevic, "The Hague Convention on Choice of Court Agreements of June 30, 2005: The Elephant that Gave Birth to a Mouse" (2006) 13:1 Sw J Trade Am 1. But a renewed attempt to develop an enforcement-only instrument has been afoot since 2012. See Hague Conference on Private International Law, "The Judgments Project: Special Commission on the Judgments Project," online: <www.hcch.net/en/projects/legislative-projects/judgments>.

78. Convention on the Recognition and Enforcement of Foreign Arbitral Awards, 10 June 1958, 330 UNTS 38 (entered into force 7 June 1959) [New York Convention]. The New York Convention was ratified by Canada in 1986 .

79. Hague Convention, supra note 4, arts 8(2), 9(c). The Hague Convention outlines two rules dealing with default judgments that seek to protect the procedural rights of the absent defendant.

80. Ibid, art 9(e). There are special rules in the Hague Convention regarding damages and settlements. See ibid, arts 11, 12. 
contracts should be subject to a different regime, it does not impose one. ${ }^{81}$ Finally, the Hague Convention's principle of enforcement of judgments rendered by designated courts is also consistent with the Canadian approach according to which jurisdiction based on consent is recognized as "appropriate," and therefore sufficient to meet the jurisdictional hurdle for recognition developed for interprovincial and international judgments under Morguard Investments and Beals $v$ Saldanha. ${ }^{82}$ As for other defences at the judgment stage, again, there is significant convergence in admitting procedural and public policy objections. ${ }^{83}$

Vaughan Black's article to the ULCC on forum selection clauses in Canadian common law and the Hague Convention presented a detailed and comprehensive review of the issue in 2007. At that point, he concluded that "the differences between the Convention and existing Canadian law [are] slim, [and] arguably they are getting slimmer." 84 The main difference was not of principle but of method:

The main dissimilarities between the Convention and the common law relate not to deep discrepancies about the general shape of the law or the goals to be pursued, but rather to legal method - that is, to how those goals should be pursued. To be more specific, the Convention seeks to define any exceptions to its general goals in narrow and exhaustive language - language that adopts bright-line rules that could easily be incorporated in a statute without significant change, or indeed without any change. In contrast, the common law, as it frequently does, seeks to preserve a measure of

81. As indicated in the introduction, Quebec law declares that forum selection clauses are not binding in these types of contracts (see art 3149 CCQ). Ontario does not have any special legislation for employment contracts and I am not convinced that a combination of sections 7 and 100 of the Consumer Protection Act, 2002, SO 2002, c 30, Schedule A has the same effect as Quebec law for consumer contracts. The Uniform Law Conference of Canada has adopted a uniform jurisdiction and choice of law regime for consumer contracts in common law Canada but it has not yet been adopted by any jurisdiction. See Uniform Jurisdiction and Choice of Law Act (2004), Uniform Law Conference of Canada, online: <www.ulcc.ca/en/uniform-acts-new-order/current-uniform-acts/739-jurisdiction/ civil-jurisdiction/2063-jurisdiction-and-consumer-protection>.

82. Morguard Investments, supra note 12; Beals v Saldanha, 2003 SCC 72, [2003] 3 SCR 416 [Beals].

83. The Hague Convention rule regarding potential non-enforcement of punitive damages awards is permissive only and therefore does not conflict with Canadian precedents that have refused to see these as necessarily against public policy. See Beals, supra note 82 at para 76; Old North State Brewing Co v Newlands Services Inc (1998), 47 BCLR (3d) 258, 155 DLR (4th) 250 (CA); and most recently, Tracy (Litigation Guardian of) $v$ The Iranian Ministry of Information and Security, 2016 ONSC 3759 at para 108, 400 DLR (4th) 670. For a review under Saskatchewan's statutory scheme (The Enforcement of Foreign Judgments Act, SS 2005, c E-9.121), see Britton v Simon Estate, 2016 SKQB 30, 395 DLR (4th) 139.

84. Black, "Hague and Common Law," supra note 6 at para 2. See also H Scott Fairley \& John Archibald, "After the Hague: Some Thoughts on the Impact on Canadian Law of the Convention on Choice of Court Agreements" (2006) 12:2 ILSA J Intl \& Comp L 417. 
flexibility, open-endedness and judicial discretion, and to eschew a definitive a priori inventory of exceptions because such a closed list might render a court incapable of reaching a fair result in all cases. To a considerable extent, therefore, a preference for one or the other of these approaches - the Convention or the common law will be conditioned by one's general preference for either (1) certainly and ex ante knowability, perhaps at the risk of rigidity and the cost of occasionally failing to do justice in every case, or (2) an adaptable and open-textured regime that prizes justice in the individual case but achieves that (if at all) only at the cost of vagueness of language and consequently less certainty of outcome. ${ }^{85}$

In other words, should the Hague Convention be implemented in Canada, that would mean replacing the ad hoc judicial discretion based on "strong cause" with a specific obligation to enforce forum selection clauses with limited exclusions that do not include most of the factors from Pompey. The acceptability of that trade-off would obviously depend on the gains accruing as a result of ratification of the Hague Convention that would justify giving up some aspects of the "strong cause" test not replicated in the Hague Convention.

Written in 2007, Black's report could not fully consider the impact of CJPTA jurisprudence on that question. Still, he suggested that for CJPTA jurisdictions, implementation of the Hague Convention would require stating that the latter "prevailed over that province's CJPTA, or at least over s. 11 of that statute." 86 This statement presaged the uncertainty relating to the manner in which the CJPTA could be used to deal with forum selection clauses, as exemplified in the case law from British Columbia and Saskatchewan. As discussed above, this uncertainty has been largely eliminated by the Supreme Court of Canada's decision in Facebook.

It remains accurate to state that the CJPTA, as currently drafted, cannot accommodate the jurisdictional obligations that would flow from implementation of the Hague Convention. Of course, implementation legislation could expressly state that it supersedes the CJPTA. In addition, given that the Hague Convention is directed only at international situations, provincial legislatures would not be bound to endorse it in cases where both the forum seized and the forum selected are in Canadian provinces. ${ }^{87}$ As such, the CJPTA would have a continuing role to play in interprovincial cases. But even for those cases, the current situation is

85. Black, "Hague and Common Law," supra note 6 at para 22 [emphasis in original].

86. Ibid at para 43 .

87. Hague Convention, supra note 4, art 1(2). Article 1(2) of the Hague Convention specifies that it applies "unless the parties are resident in the same Contracting State ... and [the dispute is] connected only with that State." In other words, an interprovincial dispute involving Canadian-resident parties is not within the scope of the Hague Convention. 
not without ambiguity given that there remain gaps even after Facebook, such as the treatment of section 3(c) of the CJPTA and the ad hoc evaluation of forum selection clauses in consumer cases.

There may thus be more work to be done following Facebook in terms of dealing with forum selection clauses in CJPTA jurisdictions. Legislatures in those jurisdictions might choose not to wait for a future decision and consider amending their statutes in order to clarify how forum selection clauses are to be treated in a comprehensive matter, whether these designate or exclude the forum seized by the plaintiff. Indeed, the legislatures are not bound by the Supreme Court of Canada's interpretation in Facebook of its own case law in Pompey and Teck Cominco or its views on general principles governing forum selection clauses. There is nothing preventing legislatures from choosing to follow a different path, and removing discretion (as Quebec has done), as there is no indication of any constitutional impediments in this area. Another option would be for the ULCC to propose a revision to the CJPTA to include all aspects of forum selection clauses, thereby providing a uniform model both for provinces who have already adopted the CJPTA and those considering it later. If proposals for modification of the CJPTA follow the majority of the Supreme Court of Canada in Facebook and subject forum selection clauses in consumer contracts to a distinct enforcement regime, this might better ready CJPTA jurisdictions for acceptance of the Hague Convention. ${ }^{88}$

Since the advent of the CJPTA, international jurisdiction in Canadian common law provinces has followed a bifurcated path: those provinces that have adopted the statutory regime and those that continue to rely on the common law. Yet, the CJPTA's failure to deal comprehensively with forum selection clauses has allowed for the continued relevance of the common law to deal with enforcement of those clauses even in CJPTA provinces, as recently confirmed by the Supreme Court of Canada in Facebook. This is not an obstacle to the adoption of the Hague Convention in CJPTA provinces (or in non-CJPTA provinces for that matter) given the Canadian common law's largely pro-enforcement approach to forum selection clauses, at least in commercial cases. But insofar as the CJPTA continues to present a gap in international jurisdiction with respect to the regulation of forum selection clauses, it would benefit from revisions for internal purposes which should be undertaken with a view to facilitating, or at least not impeding, the eventual adoption of the Hague Convention by Canada.

88. Arguably, even non-CJPTA provinces might more readily accept the Hague Convention's exclusion of consumer contracts following Facebook. 